\title{
A Microwave Assisted Synthesis of Heterometallic Metal Sulphur Assembly Mimicking the Model of $\mathrm{Cu}-\mathrm{Mo}$ Antagonism
}

\author{
JAY KUMAR ${ }^{1}$, RAMJEE SAH ${ }^{2}$ and ASHOK KUMAR YADAV ${ }^{1 *}$ \\ 'Department of Chemistry, B. N. Mandal University, Madhepura-852113, Bihar, India. \\ ${ }^{2}$ Department of Chemistry, B. R. A. Bihar University, Muzaffarpur-842001, Bihar, India. \\ ${ }^{*}$ Corresponding author E-mail: yadavkrashok@yahoo.co.in
}

http://dx.doi.org/10.13005/ojc/360613

(Received: September 30, 2020; Accepted: November 22, 2020)

ABSTRACT

\begin{abstract}
Heterometallic metal sulphur assemblies containing coinage metals and molybdenum as well as tungsten have already been studied in prebiotic condition of $\mathrm{H}_{2} \mathrm{~S}$ and carcinogenic solvent like DMSO and DMF. Recently an attempt has been made to study the similar system under eco-friendly system using green-chemistry technique. The products were characterized on the basis of chemical and spectroscopic studies under a mimicking approach to a synthetic model system relevant to copper-molybdenum antagonism.
\end{abstract}

Keywords: Green Chemistry, Copper molybdenum antagonism,

Transition metal sulphur assemblies, Calcogenides, Ruminants.

INTRODUCTION

Green chemistry opens a new challenging area towards the synthesis of chemical materials. Since its birth over a decade ago the field of green chemistry has specifically designed to meet a challenging task in the synthesis of transition metal complexes ${ }^{1}$. Remarkably in many cases, the mechanochemical synthesis is actually faster and more convenient than the original solvent based conventional methods. Environmental concern provides a compelling incentive to develop chemical reactions that minimize the waste production and be eco friendly. Using a new synthetic approach, few complexes of tetrathiomolybdate with copper were synthesized and subjected their bio-relevancy to copper molybdenum antagonism².

A green chemistry approach for chemical synthesis involves microwave exposure of reactants in presence of solvents. Metal complexes with sulphur donor ligands have received a great interest in bioinorganic chemistry a synthetic analogue of metalsulphur protein mimicking copper-molybdenum antagonism ${ }^{3,4}$.

It is generally accepted that a thiomolybdate ions, $\mathrm{MoO}_{4-x} \mathrm{~S}_{x}^{2-}$ where $\mathrm{x}=1-4$, play a central role in molybdenum induced copper deficiency in ruminants. It has also been demonstrated that the thiomolybdate ions can readily form under condition that simulate those in the animal's rumen.

This is an Open Access article licensed under a Creative Commons license: Attribution 4.0 International (CC- BY). Published by Oriental Scientific Publishing Company @ 2018

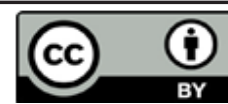


A number of transitional mental with thiometallate aggregation have been reported using conventional solvent-based, thermally induced methods in prebiotic environmental condition of $\mathrm{H}_{2} \mathrm{~S}$ gas. The attempted synthetic procedure in this article comparison to conventional route offers high yields, eliminates the use of toxic and expensive organic solvents and reduced multistep synthesis to one-step, reaction temperature and reaction time from several hours to few minutes which leads to the development of clean environmentally being procedure. $^{5}$

The formation of thiomolybdate from molybdate and hydrogen sulphide in aqueous ammonical media has been studied under conditions which simulate the fluid phase in the rumen. The thiomolybdates have been implicated as the active intermediates in the widespread molybdenum induced copper deficiency that affects ruminants. ${ }^{6,7}$

The biological antagonism between copper and molybdenum was discovered when cattle grazing pstures high in molybdenum were found to develop a syndrome characterized by diarrhoea, growth retardation, anaemia and achromotrichia which could be prevented by administering copper. This system was subsequently reported in non-ruminants, but further studies revealed important differences in the nature of the antagonism. In ruminants, dietary sulphate potentiated a Cu-Mo antagonism which decreased tissue $\mathrm{Cu}$ concentration but in non-ruminants, sulphate alleviated an antagonism which increased tissue $\mathrm{Cu}$. It has been observed that thiometallates of molybdenum and tungsten reacts with other transition metal and also with nontransition metal salts to form series of heterometallicmetal sulphur assemblies. The synthesis as well as the reactivities of such metal-sulphur assemblies specially in term of molybdenum and tungsten have already been attempted in last decade in solution phase that was not eco-friendly. ${ }^{8-10}$

In this paper authors report the synthesis of similar products using a different synthetic approach, a green chemistry. The advantage of this approach is for its clean and toxicity free chemistry avoiding the use of ammonia and hydrogen sulphide gas.

\section{MATERIALS AND METHODS}

All the chemicals used are of AnalaR grade.

\section{Preparation of starting materials and complexes:} Copper(I)thiocyanate, CuSCN:

White crystalline powder of CuSCN was prepared as mentioned in literature using precipitation reaction between copper sulphate solution and ammonium thiocyanate solution. ${ }^{11}$

\section{Ammonium tetrathiomolybdate, $\left(\mathrm{NH}_{4}\right)_{2} \mathrm{MoS}_{4}$ :}

Ammonium heptamolybdate $(1.0 \mathrm{~m} \mathrm{~mol})$ was grinded with dry disodium sulphide $(28.0 \mathrm{~m}$ mol) and dry ammonium chloride $(56 \mathrm{~m} \mathrm{~mol})$ to make almost homogeneous mixture. The mixture was placed in open Petri-dish and was allowed to irradiate at microwave frequency $3.67 \mathrm{GHz}$ for 5 min under constant stirring. After getting cool down at room temperature, the reaction product was allowed to leach with $30 \mathrm{~mL}$ acetonitrile. A deep red coloured solution was filtered and $30 \mathrm{~mL}$ dry ether was layered on the top of clear filtrate. Deep red needle shaped crystals were obtained after standing over night. The product was identical to ammonium salt of tetrathiomolybdate as reported earlier and characterized as $\left(\mathrm{NH}_{4}\right)_{2} \mathrm{MoS}_{4}$.

Tetraethylammonium thiocyanato copper(I) tetrathiomolybdate, $\left(\mathrm{Et}_{4} \mathrm{~N}\right)_{2}\left[\mathrm{NCSCuMoS}_{4}\right]$ :

Ammonium tetrathiomolybdate $(1.0 \mathrm{~m} \mathrm{~mol})$ and copper $(\mathrm{I})$ thiocyanate $(1.0 \mathrm{~m} \mathrm{~mol})$ was mixed thoroughly to make a homogeneous fine powder, and then subject to irradiate with radiation $(\lambda=400$ $\mathrm{nm}$ ) of violet light for an hour. The colour of mixture changed to reddish purple. The compound was unstable to air with liberation of ammonia smell. The exposed material is dissolved in minimum amount of water and stabilized using proper cation of tetraethyl ammonium ion. The compound was characterized as $\left(\mathrm{Et}_{4} \mathrm{~N}\right)_{2}\left[\mathrm{NCSCuMoS}_{4}\right]$ based on elemental and vibrational spectral analysis.

\section{Tetraethylammonium thiocyanato copper(I)} dioxodithiomolybdate $\left(\mathrm{Et}_{4} \mathrm{~N}\right)_{2}$ [NCSCuMoO $\mathrm{N}_{2}$ ]:

The compound was prepared on exposure to microwave irradiation at $3.67 \mathrm{GHz}$ to the powder mixture of ammonium heptamolybdate $(1.0 \mathrm{~m} \mathrm{~mol})$, copperthiocyanate $(1.0 \mathrm{~m} \mathrm{~mol})$, sulphur powder $(16.0 \mathrm{~m} \mathrm{~mol})$ and sodium metal $(8.0 \mathrm{~m} \mathrm{~mol})$ for $30 \mathrm{~min}$ at constant stirring at each interval of 
5 minute. The whole mixture powder turned to brownish and finally red. The product was crystallized using tetraethyl cation and recrystallized using proper solvent. The product was characterized as $\left(\mathrm{Et}_{4} \mathrm{~N}\right)_{2}\left[\mathrm{NCSCuMoO}_{2} \mathrm{~S}_{2}\right]$.

Tetraethylammonium diamine copper(I) tetrathiomolybdate, $\mathrm{Et}_{4} \mathrm{~N}\left[\left(\mathrm{NH}_{3}\right)_{2} \mathrm{CuMoS}_{4}\right]$ :

The experimental procedure was performed using the experimental detail in 4 by using the same material in same proportion but using the exposure of microwave irradiation of $3.67 \mathrm{GHz}$ instead of using violet radiation. The product was free from SCN stretching vibration under i.r. spectral analysis.

Tetraethylammonium bipyridyl coppe(I) tetrathiomolybdate, $\left(\mathrm{Et}_{4} \mathrm{~N}\right)\left[\right.$ bpyCuMoS $\left._{4}\right]$ :

The same procedures were adopted using $\left(\mathrm{NH}_{4}\right)_{2} \mathrm{MoS}_{4}(1.0 \mathrm{~m} \mathrm{~mol})$, CuSCN $(1.0 \mathrm{~m}$ $\mathrm{mol}), \alpha$ - $\alpha$ 'bipyridyl $(1.0 \mathrm{~m} \mathrm{~mol})$ under exposure of microwave irradiation at $3.67 \mathrm{GHz}$. Finally the product was stabilized with tetraethyl ammonium salt.

Bis-bipyridyl copper(I) tetrathiomolybdate, [(bpy) $\left.{ }_{2} \mathrm{Cu}_{2} \mathrm{MoS}_{4}\right]$ :

An almost homogeneous fine powdered mixture was prepared mixing $1.0 \mathrm{~m} \mathrm{~mol}$ each of ammonium tetrathiotunstate, copper thiocyanate and $\alpha$ - $\alpha^{\prime}$ bipyridyl together. The grinded powder was moisten with few drops of ethanol and finally exposed to microwave irradiation at $5.85 \mathrm{GHz}$ for $30 \mathrm{~min}$ at constant stirring. After completion of reaction the product subjected for conductance measurement. The compound was insoluble in polar solvents like $\mathrm{CH}_{3} \mathrm{CN}$ and DMF but fairly soluble in $\mathrm{CH}_{2} \mathrm{Cl}_{2}$. On the basis of elemental and i.r. spectral analysis the compound was characterized as [(bpy $\left.)_{2} \mathrm{Cu}_{2} \mathrm{MoS}_{4}\right]$.

Tris-triphenylphosphine copper(I) tetrathiomolybdate, $\left[\mathrm{Cu}_{2}\left(\mathrm{Ph}_{3} \mathrm{P}\right)_{3} \mathrm{MoS}_{4}\right]$ :

This compound was prepared using the similar synthetic procedure as for mentioned above. The only change was the use of triphenyl phosphene in place of $\alpha$ - $\alpha$ 'bipyridyl in reaction mixture during the progress of reaction.

\section{RESULT AND DISCUSSION}

Chemical reactivity: The synthetic preparation of ammonium tetrathiomolybdate and ammonium tetrathiotungstate (VI) under the microwave assisted programme is steochiomic one and it is shown as follows:

For $\left(\mathrm{NH}_{4}\right)_{2} \mathrm{MoS}_{4}$ :

$\left(\mathrm{NH}_{4}\right)_{6} \mathrm{Mo}_{7} \mathrm{O}_{24}+28 \mathrm{Na}_{2} \mathrm{~S}+56 \mathrm{NH}_{4} \mathrm{Cl} \rightarrow 7\left(\mathrm{NH}_{4}\right)_{2} \mathrm{MoS}_{4}$ $+56 \mathrm{NaCl}+48 \mathrm{NH}_{3} \uparrow+24 \mathrm{H}_{2} \mathrm{O} \uparrow$

For $\left(\mathrm{NH}_{4}\right)_{2} \mathrm{WS}_{4}$ :

$\mathrm{Na}_{2} \mathrm{WO}_{4}+4 \mathrm{Na}_{2} \mathrm{~S}+{ }_{10} \mathrm{NH}_{4} \mathrm{Cl} \rightarrow\left(\mathrm{NH}_{4}\right)_{2} \mathrm{WS}_{4}+10 \mathrm{NaCl}$

$+8 \mathrm{NH}_{3} \uparrow+4 \mathrm{H}_{2} \mathrm{O} \uparrow$

The advantage of this synthetic route over the conventional method as reported in literature that the conventional method require a $30 \mathrm{~min}$ regular passage of $\mathrm{H}_{2} \mathrm{~S}$ gas, a toxic one, through ammonical solution of molybdate solution for $\left(\mathrm{NH}_{4}\right)_{2} \mathrm{MoS}_{4}$ while for $\left(\mathrm{NH}_{4}\right)_{2} \mathrm{WS}_{4}$ it requires a regular stream of $\mathrm{H}_{2} \mathrm{~S}$ gas for $8 \mathrm{~h}$ through the ammonical solution of tungstate at $60^{\circ} \mathrm{C}$ temperature.

In binary sulphido complexes, copper is normally tetrahedrally or octahedrally oriented with surrounding ligand. In complex 4, copper is bonded to molybdenum through sulphur bridge and S of SCN group. Under microwave irradiation for a molybdenum to show antagonism with copper it must be associated with two sulphur group. A molybdate with all four oxo group is reluctant towards antagonism with copper. In natural process, the desulfo bacteria provide sulphur to the molybdate ion present in soil to get antagonise with copper. Under the higher frequency of microwave the coordinate SCN- group replaced by ammonia molecule generated by auto-dissociation of $\mathrm{NH}_{4}{ }^{+}$ion of $\left(\mathrm{NH}_{4}\right)_{2} \mathrm{MoS}_{4}$.

$$
\begin{aligned}
& \left(\mathrm{NH}_{4}\right)_{2} \mathrm{MoS}_{4}+\mathrm{CuSCN} \rightarrow\left(\mathrm{NH}_{4}\right)_{2}\left(\mathrm{SCNCuMoS}_{4}\right) \\
& 11 \\
& 2 \mathrm{NH}_{4}{ }^{+}[\mathrm{SCNCuMoS}]^{2-} \\
& \text { 1l } \\
& 2 \mathrm{NH}_{3}+2 \mathrm{H}^{+} \\
& 2 \mathrm{NH}_{3}+2 \mathrm{H}^{+}+\left[\mathrm{SCNCuMoS}_{4}\right]^{2-} \rightarrow\left[\left(\mathrm{NH}_{3}\right)_{2} \mathrm{CuMoS}_{4}\right]+ \\
& \downarrow \mathrm{Et}_{4} \mathrm{NCl} \\
& \left(\mathrm{Et}_{4} \mathrm{~N}\right)\left[\left(\mathrm{NH}_{3}\right)_{2} \mathrm{CuMoS}_{4}\right]+\mathrm{HCl}
\end{aligned}
$$

The use of $\alpha$ - $\alpha^{\prime}$ bipyridyl substitute the ammonia on account of its stronger lingan than $\mathrm{NH}_{3}$. 
$\left(\mathrm{Et}_{4} \mathrm{~N}\right)\left[\left(\mathrm{NH}_{3}\right)_{2} \mathrm{CuMoS}_{4}\right]+\alpha, \alpha^{\prime}$ bipyridyl $\rightarrow(\mathrm{Et} 4 \mathrm{~N})[($ bpy $)$ $\left.\mathrm{CuMoS}_{4}\right]$

On the application of even higher frequency range up to $6 \mathrm{GHz}$ promote the extension of nuclearity of complex with coupling of two $\mathrm{Cu}(\mathrm{I})$ to molybdenum.

$$
\begin{aligned}
& \left(\mathrm{NH}_{4}\right)_{2} \mathrm{MoS}_{4}+\mathrm{CuSCN}\left(\mathrm{NH}_{4}\right)_{2} \rightarrow\left(\mathrm{SCNCuMOS}_{4}\right) \\
& \text { - HSCN } \\
& \left(\mathrm{NH}_{4}\right)_{2}\left(\mathrm{SCNCuMoS}_{4}\right) \rightarrow \mathrm{H}\left[\left(\mathrm{NH}_{3}\right)_{2} \mathrm{CuMoS}_{4}\right] \\
& 3.67 \mathrm{GHz} \\
& -\mathrm{H} \\
& \text { bpy }
\end{aligned}
$$

It has been observed that the use of pyridine during the course of microwave irradiation of powder mixture expands the nuclearity of complex with the isolation of resultant product of $\left[\mathrm{Cu}_{4} \mathrm{py}_{4}(\mathrm{SCN})_{2} \mathrm{MoS}_{4}\right]$.

\section{Spectral analysis:}

Electronic spectra were obtained on Schimdzu $\lambda_{2}$ double beam spectrophotometer using matched quartz cell. The solvents used were of analytical grade. Electronic spectroscopy of thiometallate complexes particularly with metal containing open $d$-shell show the involvement of delocalized molecular orbitals characteristics of strong interaction between the central metal and thiometallate ligand. The simplified molecular orbital scheme for $\mathrm{MS}_{4}{ }^{\mathrm{n}}$ ion with $\mathrm{T}_{\mathrm{d}}$ symmetry suggests the involvement of $\pi$ bonds which is also demonstrated by various other physical measurements. The known complexes of the type $\left[\mathrm{M}^{\prime}\left(\mathrm{MS}_{4}\right)_{2}\right]^{2-}$ show characteristic absorption bands whose proportions are only roughly comparable to those in free thiometallates. The $S \rightarrow M$ transition in these complexes is split due to the lowering of local symmetry about the central atom of the $\mathrm{MS}_{4}{ }_{4}^{2-}$ unit. Because to the strong $\mathrm{M} \rightarrow \mathrm{L}$ interaction, the spectra in the region of ligand internal transitions depends markedly on the nature of the central atom. Thus, there is a characteristic splitting of the $v_{1}$ band of $\mathrm{MS}_{4}{ }^{2-}$ in the nickel complex. In contrast, the longest wavelength band in the corresponding thiomolybdate analogue is strongly shifted in the direction of longer wavelength. The electronic spectra of the M'-M-S complexes show characteristic absorption bands whose positions are roughly comparable to those in the thiometallates.
The $v_{1}$ absorption in the thiometallate ions generally splitted on complexation due to the lowering in symmetry. Whenever, the central metal (M') contains open d-shell configuration, the spectra in this region of ligand internal transition markedly change due to strong metal ligand interactions. Furthermore, the coordination geometry of the central metal, for example in the trimetallic system, causes a considerable perturbation of the electronic structure of the ligand. Most of the weak $d-d$ transitions may lie under envelop of the strong ligand to metal and metal to ligand charge transfer. Complexes containing $\mathrm{d}^{10}$ central atom should give less complex electronic spectra which mainly correspond to ligand internal transitions of the free ligand ions.

\section{IR spectra:}

IR spectra of the complexes were recorded in the range of 4000 to $400 \mathrm{~cm}^{-1}$ and 4000 to $200 \mathrm{~cm}^{-1}$ on Perkin Elmer model spectrometer. Samples were prepared as KBr pellets. The pertinent IR spectroscopic data of the complexes are tabulated in Table 3. The structure of the thiometallate complexes of the type $\left[\mathrm{M}^{\prime}\left(\mathrm{MS}_{4}\right)_{2}\right]^{2-}$ have been determined by IR spectroscopic investigations ${ }^{6-10,12}$. Outcome of these studies have now made it possible to characterize especially the bidentate nature of these ligands. In practice the terminal M-S groups are characterize by one or two vibrational frequencies between 480 and $520 \mathrm{~cm}^{-1}$ and the bridging $\mathrm{M}-\mathrm{S}$ group by frequencies in the range 430 to $460 \mathrm{~cm}^{-1}$. In dinuclear species like $\left[\mathrm{Cl}_{2} \mathrm{FeMoS}_{4}\right]^{2-}$, the $v(M-S)_{b r}$ and $v(M-S)_{\text {term }}$ vibrations are relatively characteristics. However, $v_{\mathrm{s}}$ term is the most and $v_{\mathrm{s}} \mathrm{br}$ the least characteristic vibrations ${ }^{13,14}$. The preferential sulphur coordination over oxygen in ligands of the type $\mathrm{MO}_{2} \mathrm{~S}_{2}{ }^{2-}$ could be easily seen by comparing the spectra of complexes using $\mathrm{MO}_{2} \mathrm{~S}_{2}{ }^{2-}$ and $\mathrm{MS}_{4}{ }^{2-}$ ligands. The terminal $v(\mathrm{M}-\mathrm{O})$ and $v(\mathrm{M}-\mathrm{S})$ could be easily identified along with $v(M-S)_{b r}$ in these complexes.

\section{General properties of the complexes:}

The synthesized complexes as described contain the stoichiometry between tetrathiomolybdate and copper in the ratio 1:1, 1:2, 1:3 and 1:4 respectively as obvious from its formula assigned to these complexes. Among these only the complex having 1:1 stoichiometry are anionic and the rest are neutral in nature. The involvement of coligands invariably rests with copper-ligand attachment keeping the tetrathiomolybdate moiety intact which coordinates through sulphur to copper. All these 
complexes are red in colour, however, there is a trend of the darkening of colour when the ratio of copper is increased. Complexes synthesized with oxothiomolybdate are generally orange red to red in colour. The anionic complexes in this series are generally soluble in polar solvents like DMF and $\mathrm{CH}_{3} \mathrm{CN}$. The neutral complexes are stable in solid state and highly soluble in dichloromethane and touene. Analytical and spectroscopic data of the complexes are given in Table 1, Table 2 and Table 3 respectively.

\section{Structure of the complexes:}

Thus on the basis of elemental and spectral analysis the proposed structure of reported complexes may be as follows:

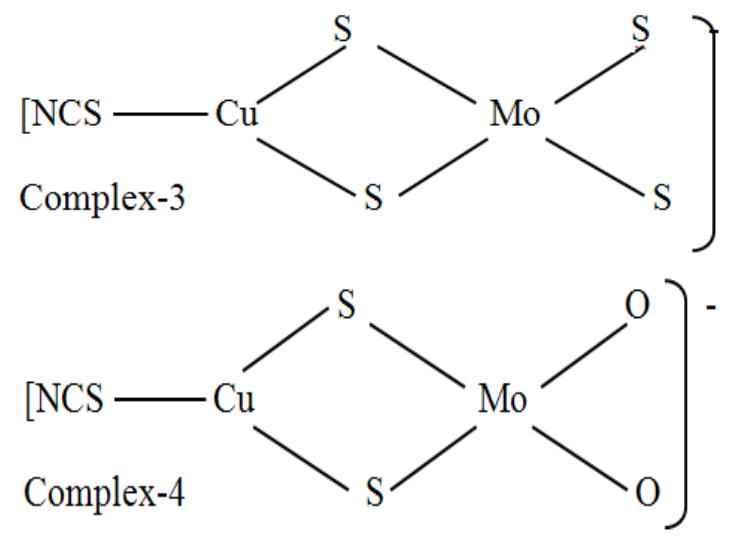

Table 1: Analytical data of the synthesized complexes

\begin{tabular}{|c|c|c|c|c|}
\hline Compound & Colour m.p & decor & $\mathrm{np} /$ trans. ten & อ. ${ }^{\circ} \mathrm{C}$ \\
\hline $\mathrm{Et}_{4} \mathrm{~N}\left[(\mathrm{bpy}) \mathrm{CuMoS}_{4}\right]$ & Red & & $>250$ & \\
\hline$\left(\mathrm{Et}_{4} \mathrm{~N}\right)_{2}\left[\mathrm{NCSCuMoS}_{4}\right]$ & Red & & $>250$ & \\
\hline$\left[(\mathrm{bpy})_{2} \mathrm{Cu}_{2} \mathrm{MoS}_{4}\right]$ & Red & & $>250$ & \\
\hline$\left[\mathrm{Cu}_{2} \mathrm{P}_{3}\left(\mathrm{C}_{6} \mathrm{H}_{5}\right)_{9} \mathrm{MoS}_{4}\right]$ & Red & & $>250$ & \\
\hline \multicolumn{5}{|c|}{$\begin{array}{l}\text { Table 2: Electronic spectral data of the synthesized } \\
\text { complexes (in } \mathrm{nm} \text { ) }\end{array}$} \\
\hline \multirow[t]{2}{*}{ Compound } & \multirow{2}{*}{$\begin{array}{c}\text { Electronic } \\
v_{1}\end{array}$} & \multicolumn{3}{|c|}{ Transitions } \\
\hline & & $v_{2}$ & $v_{3}$ & \\
\hline$\left(\mathrm{NH}_{2}\right)_{2} \mathrm{MoS}_{4}$ & 467 & 318 & 242 & 207 \\
\hline$\left(\mathrm{Et}_{4} \mathrm{~N}\right)_{2}\left[(\mathrm{bpy}) \mathrm{CuMoS}_{4}\right]$ & 495 & 338 & 260 & 242 \\
\hline$\left(\mathrm{Et}_{4} \mathrm{~N}\right)_{2}\left[\mathrm{NCSCuMoS}_{4}\right]$ & 295 & 338 & 258 & 242 \\
\hline$\left[\mathrm{Cu}_{4} \mathrm{Py}_{4}(\mathrm{SCN})_{2} \mathrm{MoS}_{4}\right]$ & 490 & 370 & 245 & 210 \\
\hline
\end{tabular}<smiles>NC1(N)CCCCC1</smiles><smiles>c1cc2n(c1)CCCc1cccn1-2</smiles>

Complex-6

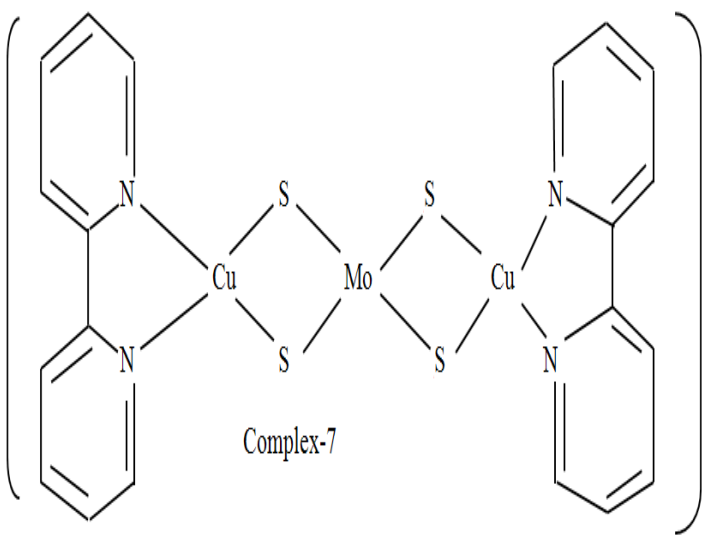

$\%$ analysis, found/(calcd)

\begin{tabular}{ccccccccc}
$\mathrm{C}$ & $\mathrm{H}$ & $\mathrm{N}$ & $\mathrm{P}$ & $\mathrm{O}$ & $\mathrm{S}$ & $\mathrm{Cl}$ & $\mathrm{Cu}$ & $\mathrm{Mo}$ \\
\hline 37.8 & 4.98 & 7.35 & - & - & 22.32 & - & 11.12 & 16.4 \\
$(37.5)$ & $(5.20)$ & $(7.30)$ & & & $(22.20)$ & & $(11.03)$ & $(16.60)$ \\
32.20 & 6.53 & 6.85 & - & - & 26.52 & - & 10.52 & 15.92 \\
$33.60)$ & $(6.60)$ & $(6.93)$ & & & $(26.40)$ & & $(10.48)$ & $(15.84)$ \\
35.84 & 3.16 & 8.34 & - & - & 19.89 & - & 19.4 & 14.80 \\
$(35.67)$ & $(3.00)$ & $(8.49)$ & & & $(19.27)$ & & $(19.00)$ & $(14.40)$ \\
56.92 & 34.08 & - & 8.40 & & $(11.40)$ & & 11.25 & 8.56 \\
$(52.49)$ & $(33.95)$ & & $(8.12)$ & & $(11.26)$ & & $(11.17)$ & $(8.44)$
\end{tabular}

Table 3: Pertinent IR spectroscopic data of the complexes

\begin{tabular}{lcccc} 
Compound & $v(\text { Mo-S })_{\text {br }}$ & $v(\text { Mo-S })_{\text {term }}$ & $v(\text { Mo-S })_{\text {term }}$ & refer. \\
\hline$\left(\mathrm{NH}_{2}\right)_{2} \mathrm{MoS}_{4}$ & -- & 472 & -- \\
$\mathrm{Et}_{4} \mathrm{~N}\left[(\mathrm{bpy}) \mathrm{CuMoS}_{4}\right]$ & 425,448 & 488,499 & -- \\
$\left(\mathrm{Et}_{4} \mathrm{~N}\right)_{2}\left[\mathrm{NCSCuMoS}_{4}\right]$ & 440,450 & 485,495 & -- \\
{$\left[(\mathrm{bpy})_{2} \mathrm{Cu}_{2} \mathrm{MoS}_{4}\right]$} & 460 & -- & -- \\
\hline
\end{tabular}




\section{CONCLUSION}

The recent investigation on the interaction of Cu-Mo-S systems reveals that the interaction, in principle, is between copper and thiomolybdate ${ }^{15}$. In vitro generation of thiomolybdate by rumen contents when combined with molybdate and sulphur sources under anaerobic conditions further supports this thiomolybdate hypothesis ${ }^{16}$. Thus, it may be assumed at this stage that copper interacts with tetrathiomolybdate to form stable Cu-Mo-S complex which seems to be stable enough to prevent copper to be available for physiological activity. From chemical point of view it would be of prime importance to know about the exactness of the species. The synthesized complexes support the phenomenon of Cu-Mo antagonism and may serve as models for further studies.

\section{ACKNOWLEDGMENT}

This research did not receive any specific grant from funding agencies in the public, commercial, or not-for-profit sectors.

\section{Conflicts of Interest}

The authors declare no conflict of interest.

\section{REFERENCES}

1. Singh, Rajesh K.; Sharda, Sadhna; Sharma, Shikha; Kumar, Shahil and Prasad, Deo Nandan; Mini-Reviews in Orgqanic Chemistry., 2020, 17, 465-484.

2. Dichen, Kaibin Tang.; Lu, Xiaming.; Zhang, Huangcei and Qian, Yital; Inorg. Chim. Acta., 2019, 82, 206-209.

3. Mishra, A. P. and Jain, Rajendra Kumar; Journal of Saudi Chemical Society., 2014, 18, 814-824.

4. Shiekh, Rayees Ahmad.; Malik, Mansood Ahmad.; Wani, Mohammad Younus and Nabi, Arshid.; Journal of South Pacific Chemical Society., 2018, 19, 418-24.

5. Jain, Rajendra Kumar and Mishra, A. P.; Jordan Journal of Chemistry., 2015, 14, 567-73.

6. Muller, A. and Diemann, E.; Chem. Commum., 1971, 65, 100-112.

7. Mullar, A.; Ahlborn, E. and Heinsen, H. H.; Z.
Anorg. Allg. Chem., 1971, 386, 102.

8. Mullar, A.; Ahlborn, E. and Heinsen, H. H.; Z.; Chem. Ber., 1971, 104, 975.

9. Kreutzer, B.; Kreutzer, P. and Beck, W.; Z. Naturforsch., 1972, 27B, 461.

10. Muller, A.; Heinsen, H. H. and Vandrish, G.; Inorg. Chem., 1974, 13, 1001.

11. A Text book of Quantitative Inorganic analysis, Vogel.

12. Schmidt, M. and Hoffmann, G. G.; Z. Anorg Allg. Chem., 1981, 452, 112.

13. Brulet, C. R.; Isied, S. S. and Taube, H.; J. Am. Chem. Soc., 1973, 95, 4758.

14. Treichel, P. M. and Werber, G. P.; J. Am. Chem. Soc., 1968, 90, 1753.

15. Muller, A.; Krickemeyer, E. and Reinsch, U.; Z. Anorg. Allg. Chem., 1980, 470, 35.

16. Bolinoer, M. and Rauchfuss, T. B.; Inorg. Chem., 1982, 21, 3947. 